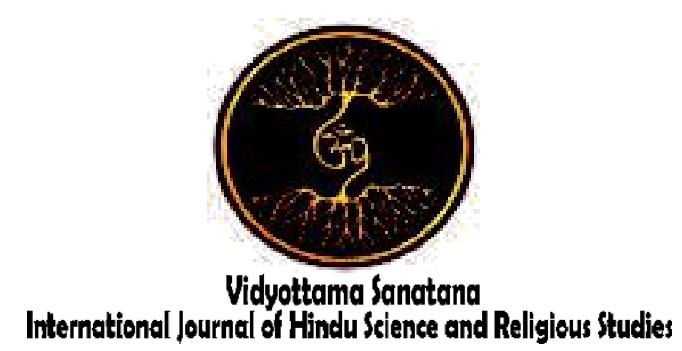

Vol. 2 No. 1 May 2018

\title{
An Ecological Aspect Of The Text Kuttara Kṇda Dewa Purāna Bangsul Concerning Mount Batukaru
}

\author{
By:
}

Luh Putu Puspawati ${ }^{1}$, I Ketut Eriadi Ariana ${ }^{2}$, and I Made Suastika ${ }^{3}$

Faculty of Arts, Udayana University

Email: ${ }^{1}$ puspawati1960@yahoo.co.id, ${ }^{2}$ eriadi.ariana99@ gmail.com,

3.madu.suastika1957@yahoo.com

\begin{abstract}
This article is intended to reveal the ecological aspect of Kuttara Kandha Dewa Purana Bangsul, a text in which it is described that Mount Batukaru is one of the holy areas in Bali Island. It is considered a place where the god of fertility resides; therefore, its ecosystem needs to be maintained. Such a signification is interesting and important to be investigated. The other reason is that, physically, the Mount Batukaru area is a water absorbing area as well as a nature reserve area. The problem of the study is how Mount Batukaru is pictured and signified in the text. The data were collected using the observation, reading, note taking, transliterating, and translating techniques. The theory of Semiotics proposed by Roland Barthes was employed. The result of the study shows that Mount Batukaru is considered the center of the energy of plants; therefore, it is recommended that plants be maintained and respected as the God's physical form. It is expected that the result of the study may be used as one of the references to save the environment as one of the world's current strategic issues.
\end{abstract}

Keywords: Environment, Mount Batukaru, Kuttara Kạ̣ḍa Dewa Purāṇa Bangsul, Ecological Literature 


\section{Introduction}

The environmental degradation resulting from the excessive exploitation of the natural resources has massively taken place in every part of the world including Indonesia. Based on the data prepared by the Global Forest Watch and Forest Watch Indonesia, Indonesia lost 4.6 million hectares of forest from 2009 to 2013. It is also stated that in 1950 Indonesia had 193 million hectares of land; however, in 2009 it had 88 million hectares of forest and in 2013 it only had 82 million hectares of forest (http://sains.kompas.com, April 2015).

The concept of sustainable development proposed by the World Commission on Environment and Development in 1987 shows that the inter and multidisciplinary approaches to overcoming the environmental pollution and the decrease in the natural resources resulting from development (Poerwanto, 2010, p. 158) are needed. According to Susilo (2008, p. 167), it is time for us not to oppose the scientific (modern) view to the local knowledge system. Everybody should necessarily and absolutely appreciate and make use of the ecological wisdom which the local knowledge system contains.

It is possible that the Old Javanese literature can offer a solution to the environmental degradation. As far as the treasure of the Old Javanese literature is concerned, the environmental aspect is the aspect which was surprisingly adopted by the poets across eras and genres. According to Zoetmulder (1985, pp. 269-270), in the Old Javanese literature the writers did not only get impressed by the nature but also by the similarities between the characteristics and forms of the nature and those of human beings. In the poets' opinion, the nature shows its reaction as what human beings do and by taking part in the human feeling moving in the middle of the nature. The poetic expressions which the Old Javanese literary work contains express what basically cause the universe and every creature in it to be united and related to one another.

It is the concept of this unity which seems to be continuously pictured in the treasure of the Old Javanese literary works, including the text Kuttara Kanda Dewa Purā Bangsul (hereinafter abbreviated and referred to as KKDPB. It is a purāna text written in the Javanese language variety spoken in Central Java narrating the gods who take care of the earth of Bali (Nusa Bangsul). The text shows that the writer seemed to understand in depth the ecosystem in Bali and to appreciate the ecosystem as the center of gods. One of the ecosystem centers mentioned is Mount Batukaru. It is the second highest mount in Bali which is rich in biological resources. It has been decided as the area of the nature preserve through the decree of the Minister of Agricultural Affairs Number 716/KPs/Um/11/1974 dated 29 November 1974 (balebengong.net/kabar-kabar).

The problems of the study focus on (1) how the area of Mount Batukaru is pictured in KKDPB, and (2) how the signification of the area of Mount Batukaru is developed in KKDPB. The study is intended to describe how Mount Batukaru is pictured and signified in KKDPB.

According to Teew (2015, p. 36), literature is not a usual communicative act; it has much more extraordinary and strange aspects than the other communicative acts. Ratna (2013, p. 111) states that literature is the second model of language system as 
introduced by Lotman (1977, p. 5) and includes metaphor, connotation, and the other characteristics of interpretations. Furthermore, Ferdinand de Saussure in Hoed (2011, p. 54) stated that language is a common means of communication using the sign system whose meaning is conventionally understood in social life. Meaning is the unity of the signifier and signified. The existence of Mount Batukaru in KKDPB is a semiotic phenomenon which is important to be investigated and informed to society. It is expected that what is signified can be used as a guide to the nature conservation program and the environment-based national development.

KKDPB was analyzed by I Ketut Eriadi Ariana (2017) in his undergraduate thesis entitled "Kuttara Kanda Dewa Purana Bangsul: A Semiotic Analysis", in which it was stated that, as a text written in the Javanese language variety spoken in Central Java, its linguistic aspect was influenced by the Balinese language grammar. Therefore, it can be classified as a new literary work influenced by the previous literary works. From the structural aspect of KKDPB, it can be seen that it was highly influenced by Ciwaism. It is clear that it comprehensively pictures the ecosystem in Bali in general and the mounts in Bali, which are believed to be a piece of Mount Himalaya in India, in particular. Ciwaism strongly affects the text; therefore, every form of ecosystem mentioned in the text was developed based on the concept of Ciwaism. In the connotation level (the secondary meaning), a mount (including Mount Batukaru) and the other ecosystem is signified as the physical shape of both Ciwa and Sakti.
The Team of Writers from the Department of Culture of Bali Province (1994) in their book entitled "Pura Luhur Batukaru" states that the existence of Mount Batukaru and Batukaru Temple is believed by the Hindus as the area where Lord Tumuruh resides. The structure of the temple and the landscape of Mount Batukaru are also described in the book.

The studies of ecological literature are still limited. Kaswadi (ejournal.fbs.unesa.ac.id) in his study entitled "Paradigma Ekologi dalam Kajian Sastra" (The Ecological Paradigm in Literary Studies) states that the cultural phenomenon and organism in one ecosystem cannot be separated from each other; therefore, the ecological paradigm can be applied in the literary work. The ecological approach to the literary work shows the ecological elements, the process in which the ecological elements interact with one another and the reasons why the literary work contains the ecological elements. The ecological approach to the literary work is not only used to understand a literary work but also to know its position and its relationship to another.

Suwardi Endraswara (2016) in his book entitled "Metodologi Penelitian Ekologi Sastra" (Methodology of Research on Literary Ecology) presents models of literary ecology, starting from the rationale, philosophical background, theories and the model of its application. It is stated in the book that literature requires and is in the physical environment (ecosystem).

Luh Putu Puspawati (2015), in her dissertation entitled "Teks Mitos Bulu Geles di Desa Tambakan Kecamatan Kubutambahan Kabupaten Buleleng" (The Mythological Text of Bulu Geles at 
Tambakan Village, Kubutambahan District, Buleleng Regency), states that the mythological text of bulu geles in the local people's life has ritual, social and educational functions which cannot be separated from the functions of Tri Hita Karana implemented to keep the relation between man and his environment, the relation between man and his fellow-beings and the relation between man and God in harmony.

\section{Method}

The theory used to analyze the meaning of the text is the theory of Semiotics proposed by Roland Barthes (2007, pp. 298$300)$. He claims that semiotics postulates the signifier (E) and signified (C). They are not equally but equivalently related. In the common language, the signifier signifies the signified; however, in the semiologic system, there are three terms which are related to one another. They are the signified, the signifier, and the sign. According to Hoed (2011, p. 45) Barthes developed this theory into the theory of metalanguage and connotation (the system of the secondary signification) which is developed from the system of primary signification.

The method and technique used in this article are divided into three; they are the method and technique of collecting data, the method and technique of analyzing data, and the method and technique of presenting the result of data analysis. The two methods were supported with the reading, note taking, transliterating, and translating techniques. The data were analyzed using the descriptive method in which facts were described before they were analyzed. The data were analyzed using the descriptive method supported with the organizing and sorting techniques.
Finally, the data were presented using the informal technique supported with the inductive technique.

\section{Result And Discussion}

\subsection{The Text Kuttara Kanda Dewa Purana Bangsul as an Ecological Literary Work}

Literally, KKDPB can be defined as a 'description of an old story narrating about the gods who reside in Bumi Bangsul'. The word kuttara (kutara) is derived from the Old Javanese word utara (angutara) meaning 'telling'; 'narrating' (Zoetmulder, 2011, p. 1354). The prefix $k a$ - is added to it. According to Ariana (2017, p. 31), the morphological process in which the word utara becomes kutara is influenced by the Balinese morphological process.

Furthermore, according to Zoetmulder (2011, p. 452), the word kanda can mean "a part of a poem". Commonly, the word kanda refers to a plot in the Ramayana story; however, as far as its development in the Archipelago is concerned, it has also been used in the other literary works. The word dewa is defined as 'dewa' (god); 'raja' (king); 'pangeran' (prince) (Zoetmulder, 2011, p. 213), and the word purāna means 'being included in the old era'; 'old story'; 'a special category of en epic (wiracarita) or 'mythological epic article' (Zoetmulder, 2011, p. 883), and bangsul (wangsul) means 'kembali' (going back); 'pulang' (going home) (Zoetmulder, pp. 136;1387).

There are several versions of KKDPB in Bali. The one used as the object of the present study was taken from the collection of texts prepared by Hindu University of Indonesia 'Universitas Hindu Indonesia' (UNHI) Denpasar. The text is written on the palm leaf manuscript which is $45 \mathrm{~cm}$ long and 
$3.5 \mathrm{~cm}$ wide and consists of 35 pieces. It is stored in a wooden box locally known as keropak. The number of the collection is $\mathrm{Lt}$. 42. It is written in the Balinese characters with jajar sambung style (it is written without any space). The text starts from page $1 \mathrm{~b}$ to $35 \mathrm{a}$. The text numbering is written on the back page (page b). Based on what is written on the colophon, the text was rewritten by I Gusti Agung Gede Suhurta in 1900 Isaka Year (1978 AD). The original manuscript of the text can be found at Anyar Palace, Banjar Tingas, Mambal Sub-district, Abiansemal District, Badung Regency.

The KKDPB stored at the Library of the Hindu University of Indonesia narrates that the sons of Hyang Pasupati, the highest lord residing at Mount Mahameru in Jambudwipa, were descending. The ecological nature of the text can be seen from the writer's accurate explanation of the Balinese ecological symbols, function and meaning.

KKDPB is strongly influenced by the ideology of Ciwaism (especially the Sidhanta Ciwaism as can be clearly seen from episode 'sargah' IV. The writer did his best to legitimate the power of Lord Ciwa as the highest god. In this case, He is named Hyang Pasupati (one of the popular names for Lord Ciwa). His sons who spread in different areas symbolized the initiation of Bali Island with Ciwaism (especially Ciwa Sidhanta). Then the syncretism of Ciwaism and Jina (Buddism) caused the Balinese people to have a belief referred to as Agama Tirtha, which is commonly well-known as Hindu Religion.

The Bangsul (Bali) Island became unstable resulting from the degradation of the leaders' morality, causing Hyang Pasupati to meditate 'tapa brata yoga samadhi'. He proposed that the Almighty God bestow Him sons who could control and maintain the Balinese people. His meditation came true, indicated by the births of wise and divine sons and priests. Then they were sent to different parts of Bali and controlled the symbols of the nature such as the mounts, lakes, beaches, rice fields, and kahyangan tiga temples (the three main temples in every traditional village). The guards and friends of every god are pictured to have controlled the smaller ecological symbols such as ravines, rivers, the upper part of the rice fields, the squares and so forth.

The existences of the gods who control the important ecosystem in Bali finally contribute to the charisma 'taksu' of the ecosystem. Spiritually, it is the taksu which has motivated the Balinese society to control and conserve the ecosystem. The local people believe that if the ecosystem controlled the above mentioned gods is disturbed, disasters will come.

In episode 'sargah' I of the KKDPB, it is explained that the eleven gods were created to stabilize the world's prosperity. They surround Bali Island and reside in the mounts created from the pieces of Mount Mahameru by their father in the maritime era. In the maritime era Hyang Pasupati cut the peak of Mount Mahameru. Two pieces were brought to Bali and became Mount Agung and Mount Batur. One piece was brought to Lombok Island and became Mount Rinjani. The smaller pieces of Mount Mahameru fell down all over Bali. One of them fell down in the western part of Bali Island and became Mount Batukaru (Batukau or Watukaru), which is currently recorded as the second highest mount in Bali. 
In episode 'sargah' II, five holy people 'rsi' referred to as Panca Pandita were created. They were supposed to write and teach religious teachings, knowledge 'sastra', and social order to the Balinese people. Then in the third episode 'sargah III', six divine sons were created known as Dewata Sadkrti. They were responsible for supporting the Balinese people's prosperity. They gave emphasis on six aspects of the environmental appreciation referred to as Girikrti (respecting the mount), Wanakrti (respecting the forest), Sagarakrti (respecting the sea), Ranukrti (respecting the lake), Swikrti (respecting the environment of rice fields), and Jagakrti (respecting the state territory).

In the last episode 'sargah IV' Hyang Pasupati (Bhatara Guru) and his wife, Bhatara Umadewi, and their son, Bhatara Gana, directly went down in the form of Gods of Tri Kahyangan residing at every traditional village. Their divine friends who accompany their existence reside at the square, cemetery, and rice fields. Everybody should appreciate and respect such symbols of the ecosystem.

\subsection{The Landscape of the Area of Mount Batukaru}

The physical aspect of Mount Batukaru as the rain water storage receptacle 'tadahan air hujan' seems to be one of the indicators motivating the local people to respect Mount Batukaru through the character Hyang Tumuwuh and Luhu Batukaru Temple. As far as the treasure of the traditional literature is concerned, enough attention is paid to Mount Batukaru and Luhur Batukaru Temple. The chronicle of Pasek 'Babad Pasek', the chronicle of Buleleng 'Babad Buleleng', the chronicle of Kusumadewa 'Babad Kusumadewa' and
KKDPB are the traditional texts which describe the existence of Mount Batukaru.

It seems that the writer of KKDPB was careful enough to observe the function of Mount Batukaru; as a result, in episode 'sargah' I it is stated that Mount Batukaru is the mount where Hyang Tumuwuh resides, and in episode 'sargah' III it is stated that Mount Batukaru is the mount where Hyang Jayanatra, who is believed to control Wanakrti, resides. The existence of KKDPB is almost similar to the existence of Mount Agung which has functioned as the center of spirituality of the Balinese people until now.

In KKDPB it is stated that Mount Batukaru, as a piece of Mount Mahameru (Himalaya) was flown by Hyang Pasupati from Jambudwipa to Bali (Bangsul). It is true that the landscape of the area of Mount Batukaru is not explained in detail in the text, as can be seen from the following quotation:

“...wuwus hana gunung-gunung sahidering bhanwa Bangsul, pinangyogakên mami ing dangu, mwang ginawan mami sangke Jambhudwipa nguni, ...

...ingsun gawun mareng Bangsul sun parah tiganên, kang sabagi dagng dadi Gunung Batur, maka dapur candi Hyanggi, soring prêtiwi talā, iakng sabagi I sornya, sun dadyakêna Gunung Rễjani, ikang pucuk ira dadi Hyang Tohlangkir, ngaran Gunung Agung. Ika pukahnya manādi pagunungan mwang gêgêr, sasor Gunung Agung Ika. Ndya lwirnya. Saka pūwa amilangi kawruhakêna pangaranya, Gunung Tapsahi, kulonnya Gunung Pangelengan, Kulonnya Gunung Mangu, kulonya Gunung Silāñjana, kulonnya Gunung 
Bratan, kulonnya Gunung Watukaru, kulonnya mwah Pagungan Nāgaloka, ..." (pp. 7b-8a).

The translation is as follows:

“... I declare that there are mounts surrounding Bangsul Island, as a result of my prayers in the past, and I brought them from Jambudwipa in the past, ...

...I brought them to Bangsul, I grouped them into three; one piece became Mount Batur, as a pile of the temple where Hyang Agni resides beneath the earth's crust. I would create Mount Rêñani from the lower part of the piece, and would create Hyang Tohlangkir, another word for Mount Agung, from the lower part of the piece. The other pieces became the mounts next to Mount Agung. What they would look like. It should be known that Mount Tapsai would be in the east; to the west of Mount Tapsai would be Mount Pangelengan; to the west of Mount Pangelengan would be Mount Mangu; to the west of Mount Wangu would be Mount Silāñjana; to the west of Mount Silāñjana would be Mount Bratan, and to the west of Mount Bratan would be Mount Watukaru (Batukaru), and to the west of Mount Watukaru would be Mount Nagaloka, ..."

From the quotation above it can be stated that the existence of Mount Batukaru is geographically located in the mountainous part of the Bali territory. It is stated that to west of Mount Beratan is Mount Batukaru. Mount Nagaloka is to the west of Mount Batukaru. As the data which could be found in the text were limited, the supporting data related to the existence of the landscape of Mount Batukaru were also obtained from the other sources.

Mount Batukaru is the second highest mount in Bali; it is 2276 above the sea level; Mount Agung is 755 meters (3031 mdpl) higher than Mount Batukaru. Administratively, Mount Batukaru is located in Tabanan Regency, the regency which is well-known as "the Bali's rice barn".

The Batukaru area has been decided to be the area of the nature preserve through the Decree of the Minister of Agricultural Affairs Number 716/Kps/Um/11/1974 dated 29 November 1974. It is $1,762.80$ hectares wide. Added together, the forests total $15,153.28$ hectares, consisting of the natural forest, which is $14,262.74$ wide and the forest of plantations, which is 890,54 hectares wide. Mount Batukaru has high rainfall and is highly rich in flora and fauna. Functionally, the forests in the area of Mount Batukaru are dominated by the Protected Forest, which is 11,899.32 hectares wide, and the forest used for touristic activities 'Hutan Taman Wisata', which is 1,491.16 hectares wide (balebengong.net, 2014).

Mount Agung is a non-active volcano and has been the highest area of the old Beratan Caldera. The land around Mount Batukaru is highly fertile. Its rock structure is made of volcanic stone, basal stone and alluvial sediment. The thick layer of land covers the stone basic structure which can also be found along the watersheds and in the other places of Bali. Mount Batukaru, Mount Sanghyang, and Mount Pohen/Puhun cause water to flow through the rivers which go to the southern part of Tabanan Regency (Tim Penyusun, 1994, p. 10). 
On the foot of Mount Batukaru there is a temple in which Lord Hyang Tumuwuh is worshipped, namely the most important lord residing in Mount Batukaru. The temple is under the category of the kahyangan jagat temple (the public temple). As far as the development of the Hindu religion in Bali is concerned, the temple is currently positioned as one of what is locally referred to as pangider jagat (nawasanga) located in the west, where God is glorified in His manifestation as Mahadewa. The artifacts discovered around the temple indicate that the temple was already in existence in the $11^{\text {th }}$ century (Tim Penyusun, 1994).

\subsection{Appreciation of Plants}

In episode 'sargah' I of KKDPB, it is stated that Hyang Tumuwuh is one of 11 children created by Hyang Pasupati through the strength of His meditation 'yoga'. Hyang Tumuwuh is the fifth son born to represent the truth. His birth is narrated in the following quotation.

"...muwah ikang hari nira sajña Hyang Tumuwuh, tuhu yatmaha darmma kira, sakti tan pahinga..." (page 6b)

The translation is as follows:

"... then his younger brother is also called Hyang Tumuwuh, who is, in fact, the representation of the truth and is so powerful that none can defeat him ..." (page 6b).

The above quotation shows that Hyang Tumuwuh is a special character. If analyzed further, the word tumuwuh is derived from the word root tuwuh meaning 'growing' (Zoetmulder, 2011, p. 1309). The infix $-u m$ - is attached to it, resulting in the word 'menumbuhkan' (causing to grow).
Hyang is a pronoun used to refer to someone who is respected (in this case, it is equivalent to the word 'dewa' (lord), so Hyang Tumuwuh can be literally defined as 'the lord which causes things to grow'. Such a term of address is close to the plants. He is supposed to take care of the plants growing in the earth of Bali.

The signification of the word is continued, as the address term Hyang Rumuwuh is affirmed again in his function as follows.

"....sira Hyang Tumuwuh jumujug sireng Gunung Batukau mangraksa bumi paścima. Mahadewa kahidêpirāa, tan sah magawe kakraśmwāning rāt bhawanā, muwang sapangisinya, magawe kawêrddyāning tri śri sadanā, mwang phala bhogāpabhogga irikang rāt..." (pages 11a-11b)

The translation is as follows:

“... His excellency Hyang Tumuwuh, his Excellency directly goes to Mount Batukaru (Batukaru) to take care of the western part of the earth, as Lord Mahadewa, who always does His best to strengthen the earth and what it contains 'tri śri' sadana, and food and clothing on earth..." (pp. 11a-11b).

Based on the quotation above, it is getting clear that Hyang Tumuwuh means the 'lord who causes things to grow'. In this case, the word tumuwuh denotatively means 'causing things to grow', and connotatively means 'the lord who controls plants'. What is meant is that the writer implies that there is a divine strength over the human strength which controls plants referred to as Hyang Tumuwuh. Therefore, human beings will not be brave enough to damage plants as they like. 
Hyang Tumuwuh is a local term used to refer to Lord Ciwa (or a spiritual teacher of Ciwaism who plays a role in spreading the philosophy of Ciwaism around the area of Batukaru. In this way, the local people can easily understand the newly-known concept. The signification of Hyang Tumuwuh can be easily justified as a representation of Ciwa as $\mathrm{He}$ has decided to reside in a mount. Ciwa is the lord of mounts who resides on the peak of Mount Himalaya located in Tibet (Kailasa). As the god of mounts, He is also referred to as Bhatara Girinatha. It seems that the writer was desirous to show off the concept Ciwaism that had been well understood by the people living around Mount Batukaru. This features that the philosophy of Ciwaism has been deeply rooted in the earth of Bangsul.

Ecologically, Hyang Tumuwuh, as the god of plants, can be clearly seen from the following sentence, “, "magawe kawêrddyaning tri śri sadana, mwang phala bhogāpabhoggā irikang rāt (making (carrying on) tri śri sadana and food and clothing. Tri śri sadhana refers to three types of prosperity symbolized by Tri Dewi (Goddess Saraswati, Goddess Śri, and Goddess Laksmi). On page 17a, what is meant by "tri ngaran Saraswai, śri ngaran sārī, sadana ngaran arț" is explained as follows; (tri means sarwasati; knowledge, śri means sari; benefit; success, sadana means wealth; property).

If analyzed further, the concept tri śri sadana seems to mean that the real prosperity will come true if knowledge, food, and property are fulfilled. This is in line with the concept Catur Purusha Arta in Hinduism consisting of dharma (the truth), artha (property), kama (happiness), and moksa (freedom from reincarnation). Dharma means the truth which seems to be in line with jnana (knowledge). Property, happiness and freedom from reincarnation can only be achieved through dharma and jnana.

Prosperity can be stated to be achieved if what is referred to as phala bhogāpabhogga (foods and clothing) can be fulfilled. In this case, the phala bhogāpabhogga are produced by plants. They produce foods for human beings and other living creatures. They also produce the clothing and building materials needed by human beings. They should be appreciated as we appreciate gods as they give us things to eat. In the modern Bali Hindu tradition, there is a precious Saturday referred to as Tumpek Wariga, when the Hindus show their appreciation of plants. That is the reason why the writer presented the magnificence of plants by giving honor to Hyang Tumuwuh residing at Mount Batukaru.

The physical fact that Mount Batukaru was chosen as the mount where Hyang Tumuwuh resides is that it is a region of water absorption which is rich in biological resources. Mount Batukaru, Mount Sanghyang, and Mount Puhun cause water to flow through six rivers in Tabanan. They are (1) Otan River which flows through Selemadeg and empties into Tanjung Bulung Daya, (2) Matan River which empties into the area of Pasut, (3) Lamuk River which becomes united with the water flowing through Leh River, (4) Leh River through which water from the heart of Mount Batukaru and other springs, including the water flowing from the foot of Mount Sanghyang get united, (5) Abe River through which the water from the spring at the foot of Mount Batukaru flows to the south through the tuffaceous stone formation and the Buyan- 
Bratan lava sediment, and (6) Empas River which flows from a spring of 600 meters height (Tim Penyusun, 1994, pp. 10-11). The water flowing from those rivers causes the plants and agricultural areas through which they flow to be alive, and the rice fields in Tabanan to be fertile. Therefore, Tabanan has been well-known as the Bali's rice barn.

\subsection{Mount Batukaru and Forest Glorification}

In episode 'sargah' III the existence of

Dewata Sadkrti is narrated. Mount Batukaru is positioned as a territory controlled by Hyang Jayanatra, the second son of Lord Sadkrti who controls Wanakrti (the forest). The power of Hyang Jayanatra, as the lord controlling Wanakrti, is quoted as follows.

"...Hyang Jayanatra jumujug mareng Gunung Watukaru, madarma kayangan pangaran Daharihanan, sira wiśeșaning sarwwa dewa, rumaksa ikang wanā pakrêti, pakebonan, pagagan kunang..." (page 18a)

The translation is as follows:

“... Hyang Jayanatra immediately goes to Mount Watukaru (Batukaru), his abode is referred to as Daharihanan, he controls all gods, takes care of what is referred to as wanaprakrti, plantation, and unirrigated agricultural fields as they are ..."(page 18a).

Based on the above quotation, the function of Mount Batukaru, through the character Hyang Jayanatha, is shifted to becoming the protector of Wanaprakrti (forest glorification), plantation, and unirrigated fields. Ecologically, what is narrated in episode 'sargah' III is not basically different from what is stated in episode 'sargah' I. They focus on plants. However, in this episode 'sargah' the function and glorification of Mount Batukaru are reaffirmed.

The word wanaprakrti is derived from two words; they are the word wana meaning 'forest' and the word prakrti (krti) meaning 'glorification', 'popularity', 'commendable act' (Zoetmulder, 2011, pp.1380; 519). If combined, the word Wanaprakrti or Wanakrti can be literally translated into 'forest glorification'. In this case, wanakrti refers to an attempt which should be made by human beings to appreciate forests as an important, complex and highly useful ecosystem.

The forest in Mount Batukaru is a "green absorption' which reacts to and absorbs every raindrop. The raindrops are then processed within the rock body before they appear again as the springs flowing throughout the season. Mount Batukaru with its dense forest is the habitat of different animals. The trees, clumps of bamboo and bushes growing on the slope of Mount Batukaru produce the natural oxygen $\left(\mathrm{O}_{2}\right)$ as the main compound in the breathing process of human beings and animals. It also forms the ozone $\left(0_{3}\right)$ as the earth's mantle. It protects the earth and what it contains from the heat resulting from the sun ultraviolet ray. The atoms and the oxygen compound produced by the forest in Mount Batukaru fly freely on the atmosphere without being bound to any territory. They sincerely submit themselves to every creature that needs them in order to keep being alive.

Based on the ecological facts described above, it is not wrong if Mount 
Batukaru and its forest are worshipped by the Balinese people. They respect Mount Batukaru and its forest as the Almighty God in His manifestation as Mahadewa. The attempts made to make Mount Batukaru and its forest sacred can be observed from the ceremonies performed "to keep the human physical nature 'bhuwana alit' and the physical nature of the universe 'alam fisik manusia' balanced. The people living around Mount Batukaru highly appreciate the existence of its forest. They are not allowed to take any plant and animal living there. What is produced by the forest can only be used for particular purposes. This is certainly an attempt which is wisely taken to keep the environment sustainable.

The myths of invisible creatures and animals and holy plants living and growing around Mount Batukaru were created by society in order to remind those who are in the middle of the nature that they cannot do what they like. Being afraid, resulting from the behavior of respecting the invisible creatures and animals and holy plants, it is expected that the forest will always become maintained. When the forest is maintained by human beings, they will also be maintained by the forest. This is in line with what is quoted from Kakawin Nitisastra as follows.

"Singhā rakṣakaning halas, halas ikang rakṣeng harīnityaśa,

Singhā mwang wana tan patūt paḍa wirodhāngdoh tikang keśari,

Ring brāștang wana denikang jana tinor wrêkșanya śirṇapaḍang,

Singhānghöt ri jurang nikang têgal ayūn sāmpun dinon durlaba"

The translation is as follows.

(The lion takes care of the forest, and the forest always takes care of the lion.
It is wrong if they dispute with each other (causing) the lion to get isolated, The forest is degraded and destroyed by human beings; the trees are cut down as they like, causing the forest to be leafless,

The lion will get cornered in the ravine, unirrigated fields, open land, attacked and killed)

(Kakawin Nitisastra, I.10)

The relation between the forest and the lion (including human beings) should be like that. They are obliged to protect each other for the sustainability of life. When the forest is damaged, the ecosystem will get disturbed, and disasters cannot be avoided by every creature.

\section{Conclusions}

KKDPB is one of the literary traditional texts which is ecologically valuable. In KKDPB Mount Batukaru is stated to be a small piece of Mount Mahameru which fell down in the western part of Bali. Mount Batukaru is considered an important ecosystem as it is rich in biological sources. It is received as the holy area where Lord Ciwa resides in His manifestation as Hyang Tumuwuh (god of plants) and Hyang Jayantra (the god taking care of the forest 'Wanakrti'. Every form of the glorification of Mount Batukaru constitutes a green movement focusing on the forest and plant conservation.

\section{References}

Agastia, IBG. 1987. Sagara Giri Kumpulan Esei Sastra Jawa Kuna. Denpasar: Wyasa Sanggraha

Ariana, I.K.E.. 2017."Kuttara Kaṇụa Dewa Purāna Bangsul:Analisis Semiotik". Skripsi. Program Studi Sastra Jawa 
Kuno Fakultas Ilmu Budaya Universitas Udayana

Barthes, R.. 2007. Membedah Mitos-mitos Budaya Massa: Semiotika atau Sosiologi Tanda, Simbol, dan Representasi Cet. II (Ikramullah Mahyuddin). Yogyakarta: Jalasutra

Endraswara, S.. 2016. Metodologi Penelitian Ekologi Sastra Konsep Langkah, dan Penerapannya. Yogyakarta: Cempaka Putih

Goris, R. 1986. Sekte-sekte di Bali. Jakarta: Penerbit Bhratara Karya Aksara

Gunawan,I.K.P. 2012. Śiva Siddhānta Tattva dan Filsafat .Surabaya: Parāmita

Hoed, B.H. 2011. Semiotik dan Dinamika Sosial Budaya Edisi Kedua. Jakarta: Komunitas Bambu

Jirnaya, I.K. 2016. Arjuna di Gunung Indrakila dalam Kakawin Arjunawiwaha: Sebuah Kajian Ekosemiotik. Denpasar. Mei,144-153

Miswanto. 2015. Kekawin Nitisastra Teks, Terjemahan, dan Komentar. Surabaya: Paramita

Poerwanto,H. 2010. Kebudayaan dan Lingkungan dalam Perspektif Antropologi (Cet. V)Yogyakarta:Pustaka Pelajar.

Putra, I. D. G. R. D. (2017). The Phenomena of Plagiarism in Hindu Perspective. Vidyottama Sanatana: International Journal of Hindu Science and Religious Studies, 1(2), 160-167.

Puspawati, L.P.. 2015. "Mitos sapi di Desa Tambakan, Kabupaten Buleleng". Desertasi. Pasca Sarjana Universitas Udayana

Ratna, N.K. 2013. Teori, Metode, dan Teknik Penelitian Sastra Cet.XII. Yogyakarta: Pustaka Pelajar
Sugiharta, I. P. S. O., \& Sudarsana, I. K. (2017). Hypnotic Learning Characteristics On Sisya Brahmakunta Community In Denpasar. Vidyottama Sanatana: International Journal of Hindu Science and Religious Studies, 1(2), 132-145.

Susilo, R.K.D. 2008. Sosiologi Lingkungan. Jakarta: PT Raja Grafindo Persada

Teeuw, A. 2015. Sastra dan Ilmu Sastra Pengantar Teori Sastra Cet. V. Jakarta:

PT Dunia Pustaka Jaya

Tim Penyusun. 1994. Pura Luhur Batukaru.

Denpasar: Dinas Kebudayaan Propinsi Daerah Tingkat I Bali

Yunanto Wiji Utomo (editor).2015.Hari

Bumi dan Fakta-fakta Menyedihkan tentang Alam

Indonesia:http://sains.kompas.com/read /2015/04/22/20042431 (Diunduh 15

Agustus 2016)

Zoetmulder, P.J. 1985. Kalangwan Sastra Jawa Kuna Selayang Pandang Cet. II. Jakarta: Djambatan

Zoetmulder, P.J. dan Poedjawijatna. 1992. Bahasa Parwa I. Yogyakarta: Gadjah Mada University Press

Zoetmulder, P.J. dan S.O. Robson. 2011. Kamus Bahasa Jawa Kuno-Indonesia Cet.VI (Darusuprapta dan Sumarti Suprayitna). Jakarta:Gramedia Pustaka Utama 